\title{
Becoming Part of Mainstream America or Asserting a New Muslim-Americanness: How American Muslims Negotiate their Identity in a post 9/11 Environment
}

\section{Dominique Cadinot}

\author{
Aix-Marseille Université
}

\begin{abstract}
In 2005, historian David R. Roediger published the now-classic Working Toward Whiteness: How America's Immigrants Became White in which he recounts how immigrant minorities in the early $20^{\text {th }}$ century secured their place in the "white race" in order to qualify as fully American and be treated with fairness and respect. Muslim immigrants from the Middle-East were no exception to the process described. However, becoming white was a particularly long and arduous journey which eventually led to the 1978 Office of Management Budget directive officially categorizing Middle-Eastern immigrants as white. But the terrorist attacks of September 11, 2001 sparked new alliances between the various ethnic groups that make up the US Muslim community: Arabs, African-Americans or South-East Asians from all walks of life have joined forces in resisting discrimination and bigotry. Thus, the question arises whether common cultural heritage or faith should be the main force shaping a new collective and visible identity. Also, such process entails a questioning of hierarchies based on socioeconomic status; compared to their African-American coreligionists, American citizens of Arab descent fare much better in terms of education and wealth. The main purpose of this paper is to evaluate the impact of 9/11 on the way ArabAmerican Muslims and their community leaders re-define the boundaries of their collective identity and how they forge bonds of solidarity with indigenous Muslims. It seeks to address two related questions: How do Arab-American Muslims relate to the black-white dualist model or racial binary? What role does class identification play
\end{abstract}


in structuring social relations between Arab and African-American Muslims? While I do not negate the fact that in the US race continues to play a fundamental role in structuring social relations, I argue that it is important to pay close attention to how socioeconomic status may condition the formulation of a group identity.

Keywords: American Islam, race, collective identity, Americanness

In the wake of the 9/11 terrorist attacks, some American Muslim leaders felt it was "the best of times" to clear up misrepresentations about their community and to demonstrate their loyalty to the United States. As they refused to get drawn into the "us versus them" scenario, activists promoted interreligious dialogue and organized conferences to highlight the similarities between Islamic and American values. In response to the dramatic spike in hate crimes, protest demonstrations were staged at which participants carried banners proclaiming: "Muslims and Christians worship the same God" (MAC 2002). Moreover, because unity creates strength, intellectuals and community leaders of immigrant origin actively encouraged coalition building, as illustrated by this statement in 2001 by Mervat Hatem, the president of the Middle East Studies Association: "Muslim politics have shifted to thinking beyond immediate needs or distinct needs of distinct Muslim racial/ethnic communities" (quoted in Naber 2012, 150). Indeed, the emphasis on cohesion building naturally led advocacy groups to support the political mobilization of American Muslims in order to produce a national unified agenda. Shifting the discursive frame from parochial to broader interests represented a suitable strategy towards political cohesiveness and effective mobilization. This nascent pursuit for empowerment caught the attention of political observers and even prompted some to announce the birth of a Muslim lobby. ${ }^{2}$ In fact, the sense of being besieged, a condition brought upon by hate violence and negative media images, all but encouraged, it seemed, the strengthening of communal sentiments and the uniting of all American Muslims, both immigrants and natives.

However, the year 2001 was coincidentally marked by a dramatic in-

1 When asked about the fate of the Arab/Muslim community in the US after 9/11, Mary Rose Oakar, President of the Arab-American Antidiscrimination Committee, famously quoted Dickens's opening line: "These are the best of times and the worst of times."

2 Neo-conservative theologian Richard John Neuhaus was one of George W. Bush's informal advisors and postulated the existence of a well-structured Muslim lobby in an article entitled "One Nation Under Many Gods," published in October 2001 in the religious journal First Things. 
crease in immigration from countries where Islam is the predominant religion: more Muslims immigrated to America in 2001 than in any other year since 1992, according to the Pew Research Center $(2011,13)$. Whereas the Hart-Celler Act of 1965 had made it easier for people from present day Lebanon, Syria and Jordan to settle in the US, in 2001 new contingents of immigrants were added to the stream with many coming from countries in South-East Asia, Africa or Eastern Europe. As a result, indigenous AfricanAmerican adherents to Islam were soon confronted with alternative definitions of what being a Muslim means.

Hence, at the beginning of the new century, two contradictory dynamics were simultaneously at work; on the one hand, anti-Muslim sentiment encouraged the forging of a stronger collective identity, but on the other hand the Muslim community was becoming even more ethnically and culturally diverse.

Despite the optimistic discourse of Muslim advocacy organizations, one may ask whether, a decade and a half after the tragedy, civic and religious leaders have actually managed to establish bonds of community and develop a genuine and cohesive American Muslim identity or American ummah (the Muslim community at large). In view of the number of terrorist acts which have been carried out in the US since 2001, one would indeed tend to believe in a continued and growing effort towards collective action. However, the definition of a common agenda requires overcoming the racial and cultural divide between a great variety of immigrants and African-American Muslims, as much as it requires maintaining multiracial alliances. These questions have been the subject of a wealth of scholarly research. While some studies have focused on the emergence of a national Islamic leadership (Sirin and Fine 2008, Nimer 2002), others have investigated the difficulties encountered by community leaders in maintaining a unified American ummah (McCloud 1995). Still others have studied the tension between universalism and particularism and highlighted the vitality of African-American Islam (Curtis 2002, Chande, 2008). But the dominant narrative of the Islamic faith in America is still that it is primarily a MiddleEastern phenomenon. In fact, and even more so since 9/11, the public media and political discourse tend to conflate Arab and Muslim identities and subsequently erase the African-American Muslim experience. This article seeks to contribute to the literature by studying how immigrants from the Arab world in particular and African-American Muslims interact to define what constitutes American Islam in the post-9/11 era. Because the shaping 
of a collective identity implies the existence of commonalities and shared beliefs, I will discuss attitudes and social practices in the context of the mosque after a brief introductory section on the organizational aspects of mosque life in the US. The third part will be dedicated to an examination of the political implication of mosque-goers as well as the voting behavior of the two subgroups in question.

My analysis will draw mainly on data from two different surveys that were released in 2001 and 2011: "The Mosque in America: A National Portrait" (2001), conducted by Dr. Ihsan Bagby, Associate Professor of Islamic Studies at the University of Kentucky and sponsored by the Council on American-Islamic Relations (CAIR), based in Washington, DC, and "The American Mosque 2011: Basic Characteristics of the American Mosque, Attitudes of Mosque Leaders," also carried out by Ihsan Bagby and sponsored by various associations such as the Hartford Seminary or the Islamic Circle of North America. Although the results are only comparable in a limited sense as the questions asked were not exactly the same in their wording, both studies provide a detailed examination of how relations between the Arab and African-American Muslim subgroups have evolved over the past decade. ${ }^{3}$ Ultimately this contribution aims at providing insights on the issues surrounding the definition of "Muslim-Americanness" in the post 9/11 landscape.

\section{Organizational Aspects and Dynamics}

All studies concur that the majority of American Muslims today are foreign-born. More than $60 \%$ of US Muslims are immigrants, according to the Pew Research Center data $(2011,13)$. In terms of regional origins, four out of every ten Muslim immigrants to the US are from the Middle-East - North Africa region (Pew Research Center 2007, 7). The rest are from SouthAsia, sub-Saharan Africa, Europe, and elsewhere. However, indigenous African-American Muslims still constitute roughly a third of the whole (Pew Research Center 2011, 16). Because the US Census Bureau does not collect religion membership data, there are no official statistics on the number of

3 The two surveys which serve as a database for this study focus on the basic demographics, administration and vitality of American mosques. In addition, the surveys (which involved nearly one thousand telephone interviews) included a set of questions on the attitudes of Mosque leaders to America and involvement in American society. 
Muslims in the US. Estimates range from 3.3 million in 2016 (Mohamed $2016,1)$ to as many as 7 million (Council on American-Islamic Relations, 2015). The majority (65\%) identifies with Sunni Islam, while 11\% identify with the Shi'a tradition. Most African-American Muslims adhere to mainstream Islam and many have followed the teachings of Imam W. Deen Mohammed (until his death in 2008). However, another large portion of African-Americans belongs to a second current whose avowed goal is to create "a more authentic and normative form of Islam" (Bagby 2006, 27). In addition, there are other sectarian groups such as the Sufi and Ahmadiyyas, as well as the more unorthodox religious tradition of the Nation of Islam. ${ }^{4}$

Recently published figures show that, in the past decades, immigration from Muslim countries has increased significantly. As reported by the Pew Research Center, the total number of immigrants doubled from roughly 50,000 people a year in 1992 to 100,000 in 2012 (Mohamed 2016, 1). As a consequence, the number of places of worship in the US has increased at a tremendous rate. The 2011 Mosque Survey estimates that the number of mosques rose from 1,209 in 2000 to 2,106 in 2010, a $74 \%$ increase which implies that $80 \%$ of the houses of worship were built within the last twelve years (Bagby 2011, 5).

Understandably, as disparate peoples with different interpretations of Islam and ideological beliefs come together, one would expect congregations to be primarily shaped by identification with a particular cultural heritage. When asked about the cultural divide, the mosque leaders who were interviewed in 2001 and 2011 claimed that their congregations were in fact becoming more ethnically diverse. It was reported that only $3 \%$ of all mosques in 2011 had only one ethnic group that attended the mosquecompared to 7\% in 2001 (Bagby 2001, 3/ 2011, 4). That being said, the reports also show that three-fourths of all mosques are still dominated by one major ethnic group: Arab, African-American or South Asian. Hence, it seems that Bagby's conclusions need to be tempered. Indeed, many mosques, and some of the largest in the US, are still clearly divided along ethnic lines. For example, the Islamic Center of Detroit, which is said to be "at the intersection between all the different communities", has no AfricanAmericans on its board (Adil 2009, 1). Similarly, the Diyanet Center of America, a 20,200-square-foot mosque and cultural center that was inau-

4 For a complete overview, see Y. Y. Haddad and J. I. Smith, eds., Muslim Communities in North America (Albany, NY: State University of New York Press, 1994). 
gurated in 2016 in Lanham, Maryland by Turkish president Recep Tayyip Erdogan, is also known as the Turkish American Community Center. Although the center was built "to serve as bridge between communities," according to Turkey's head of Religious Affairs Dr. Mehmet Gormez (Ileri $2016,1)$, some critics feel that its construction serves the purpose of exporting a Turkish style of Islam and thus competing with Middle-Eastern ritual practices (Elass 2015, 1).

However, if in reality a cultural divide sometimes opposes immigrant subgroups, both the 2001 and 2011 reports conclude that African-American mosques are more likely than immigrant mosques to cater to a non-mixed audience. In some of those mosques, $90 \%$ of worshippers are African-American (Bagby 2011, 4). Of course, the residential patterns of congregation members are greatly determined by socioeconomic differences. But over the last 10 years, economic disparities have widened considerably (Sharp 2013 , 1048). As a result, Muslim congregations in urban and suburban areas are inevitably divided along racial and social lines. Compared with other subgroups, immigrants from the Arab world fare better in terms of income, education and employment, many of them having settled in the US after completing a university degree or a professional training program. Most are thus well-educated with relatively high annual median incomes. For that reason, these first- and second-generation immigrants have integrated rather well socially and economically. Conversely, the socioeconomic status of African-American Muslims is similar to that of their ethnic group in the overall non-Muslim population. A study conducted in 1999 indicated that the median family income for black Muslims amounted to $\$ 32,000$ corresponding roughly to that of the larger African-American group but far behind the more than $\$ 50,000$ earned by the average American family (Karim 2009, 38). As historian Simon Reich puts it: "African Americans remain the most disillusioned segment of the US Muslim population" $(2010,6)$.

Therefore, while African-Americans in general live and pray in urban centers, immigrants have generally settled in suburbs or ethnic enclaves. The situation in Detroit is a clear illustration of these ethnically and economically determined boundaries between groups. Muhammad's Mosque and Masjid Al Haqq, for example, are both located in a predominantly black neighborhood and consequently cater to the needs of African-American Muslims. But Masjid Al-Salaam, in Dearborn Michigan, which is part of the Detroit metropolitan area, was built in a suburb where more than $30 \%$ of the population is Arab-American. As Jamillah Karim's research demon- 
strates: "This residential division, often spoken of as an inner-city versus a suburban division, is a major theme in intra-ummah discussions" (2009, 40). One direct consequence of this socio-economic gap is that AfricanAmerican mosques are not economically as sound as immigrant mosques and tend to have lower budgets. Only $15 \%$ of African-American mosques have a budget of $\$ 100,000$ or more compared with $47 \%$ of Middle-Eastern mosques. In addition, as a result of deindustrialization and out migration, African-American mosques have, overall, the lowest rate of increase: on average, the number of participants in all mosques increased between 2001 and 2011 but African-American mosques have the lowest percentage of increase (Bagby 2001, 2011).

If social and economic disparities may explain the ethnic cleavage, many authors, however, underline the impact of religious or ritualistic dissension. As soon as new immigrants settled into their new lives, it became clear to them that the kind of Islam practiced by African-Americans did not conform to Middle-Eastern rites. Some of the rites adopted by African-American Muslims were simply incompatible with the type of religious practices they were accustomed to. As early as 1998, in a book titled Muslims on the Americanization Path?, two leading scholars, Yvonne Y. Haddad and John L. Esposito, had already pointed out the delicate coexistence of competing Islamic rituals and practices:

Some in the African-American community have become increasingly sensitive to immigrants who insist on including regional cultural preferences as an essential part of the definition of Islam and set themselves up as arbiters of Islamic norms and of what it means to be Muslim. (37)

What thus seems evident is that the influx of immigrants has not only drastically changed the demographics of the Muslim community; it has indeed challenged homegrown Muslim practices.

\section{Attitudes and Social Practices}

Islam's sacred book was revealed in Arabic. Consequently, worshippers are expected to memorize and recite the scriptures in their original form, regardless of their native tongue. Although the language used in the Qur'an is very complex and does not resemble modern Arabic, those whose origins are from the Middle-East obviously have an advantage. Being generally unfamiliar with Arabic, African-American Muslims find it difficult to estab- 
lish bonds of community with the more linguistically-trained adherents. So, in mosques where Middle-Easterners form a majority, the Salat al Jumu'ah or Friday prayer is often delivered in Arabic, a practice which further alienates African-American Muslims. In fact, the language spoken within the walls of the mosque greatly affects attendance across all subgroups. For that reason, a significant generational divide has gradually strained relationships between older immigrants and their native-born and US educated offspring. Many report feeling estranged from the local congregation. A documentary by film director Ahmed Eid and titled "Unmosqued" (2013) reveals that language illiteracy sometimes forces younger Muslims of immigrant or African-American origin to pray at home instead of attending a service delivered in a language they do not fully understand.

But beyond linguistic issues, there are more contentious matters that tend to hinder the various subgroups of achieving the ideal unified community. Gender issues, to start with, have stirred debate. A Pew Research Survey published in 2011 indicates that, compared with other Muslims, American Muslims overall are more supportive of the role of women in the society (17). However, there are some striking differences between women's roles in black and Middle-Eastern mosques. According to Bagby, in most African-American mosques, men and women do not pray separately. Only $39 \%$ of those mosques use curtains or partitions to separate worshippers by gender, while $70 \%$ of Arab mosques do $(2001,48)$. Similarly, the role given to women differs from one community to the other. Female participation is encouraged in African-American mosques with $80 \%$ of them allowing women on their boards (Bagby 2001, 57). In fact, pioneering challenges to sex-segregation have been developed by African-American Muslim female leaders. One of the most famous achievements was Aminah Wahud's historic prayer service in 2005. Now a specialist in gender and Qur'anic studies, Dr. A. Wahud was born to a Methodist family but converted to Islam while pursuing a higher education. She has been described by fellow scholars as one the most influential proponents of "gender jihad" in the Muslim world. ${ }^{5}$

But, as a majority of observers have convincingly argued, the race question is maybe the most critical among the various dimensions of inequality. For instance, Beverly Aminah McCloud contends that: "There is no racism

5 The expression was first used in her 2006 book title: Inside the Gender Jihad: Women's Reform in Islam (Oxford: One World Publication). 
in Islam, but there is plenty among American Muslims" $(1994,74)$. More recently, in her book, American Muslim Women (2008), Jamillah Karim writes, "The pursuit for acceptance causes immigrants to differentiate themselves from blacks and also drives them to perceive and treat blacks with a scorn taught by the dominant racial discourse" (28). Indeed, for Middle-Eastern immigrants becoming "white" has been a goal ever since the first contingents started settling in North America. Because in the $19^{\text {th }}$ century newcomers from the Levant were classified as "Asian," they were not eligible to become citizens. For almost a century, various successive naturalization cases issued contradictory decisions. In 1915, the Dow vs. United States decision ruled that immigrants from the Levant were white. But in 1942, a Michigan District court denied citizenship to a Yemenite petitioner on the ground that he was Muslim and, as consequence, non-white. Eventually, a 1977 Office of Management and Budget directive established that: "A person having origins in any of the original peoples of Europe, North Africa, or the Middle East" would now be classified as white (quoted in Loue 2006, 27).

The apparent determination of Arab-Americans to gain "honorary whiteness" has obviously been interpreted by African-American Muslims not only as inferential anti-black racism but also as heretical and blatantly in contradiction to the teachings of the Qur'an, which purportedly recognizes equality and rejects racial discrimination. Although African-American proto-Islamic leaders had advocated racial separatism that part of their theology was actually abandoned over time. Upon returning from his pilgrimage to Mecca, Malcolm X embraced the color-blind perspective of orthodox Islam and declared: "American needs to understand Islam because this is the one religion that erases from its society the race problem" (quoted in Hall 2003, 229). This was the beginning of a movement towards Islamic orthodoxy, leading to Warith Deen Muhammad's bringing the community into line with Sunni Islam and rejecting in the late 1970's his predecessors' anti-white theology. Yet, despite the African-American community's new adherence to mainstream Islam, anti-black racism still pervades Muslim institutions and mosques. In order to address the multiple and intersecting forms of segregation, a group of community leaders and scholars founded in 2014 a new organization named MuslimARC (The Muslim Anti-Racism Collaborative), which specifically deals with racial justice and issues of anti-blackness. Focusing on education, outreach and advocacy, the organization seeks, despite antagonistic trends, to build "multi-ethnic coalitions for racial equity" (MuslimARC 2016, 1). 
However, some African-American Muslim leaders today are questioning and challenging the common dialectic between immigrant and indigenous Islam. Sherman Jackson, for instance, specializes in Islamic law and feels that the move to Sunni Islam has dislocated African-American Muslims' ability to address the specific needs and problems affecting the black community. In addition, when orthodox Sunni Islam became the basis of authority, Blackamericans (a coinage by S. Jackson) were relegated to the status of second class Muslims: "The false universals invoked by many immigrant and overseas Muslims [...] exclude Blackamerican concerns and simply assume them to be subsumed under the models settled on in the Muslim world" (Jackson 2009, 3). Therefore Jackson feels that AfricanAmerican Muslims should become more proficient in the religious sciences of Sunni tradition and speak out with a distinctively black American voice. In other words, he considers that Black Islam is a thoroughly American phenomenon that does not need the approval of immigrant Arab Muslims.

The large numbers of immigrants who settled in the US in the last decades of the $20^{\text {th }}$ century brought with them new religious traditions and practices which eventually disrupted the established patterns of AfricanAmerican Islam. Because religious institutions play a significant role in the political mobilization of citizens, let us now turn to a brief analysis of national policy issues: how does the divide between Middle-Eastern and African-American Muslims affect the formulation of a common political agenda?

\section{Political Implication and Voting Habits}

Many studies have shown that religiosity (measured by service attendance) has, what Ruiter and De Graaf call, a "spill-over effect" on the political mobilization of citizens $(2006,1)$. This phenomenon suggests that religious volunteering often leads to more political engagement. According to Ihsan Bagby's surveys, Arab and African-American mosques contrast in the way their congregants engage in political activities. The answers show that, although the overwhelming majority of American Muslims feel that they should be involved in politics, black Muslims are less likely to share that feeling: $23 \%$ of black leaders disagree with the idea that Muslims should participate in the political process while only $2 \%$ of Arab leaders share that opinion (Bagby 2001,33). Another study by Amaney Jamal from Princeton University concludes that: "The African American mosque 
participation is not channeled to political ends" $(2005,535)$. Various explanations have been proposed to account for the fact that African-American Muslims are apparently reluctant to engage in politics. Jamal, for example, claims that the long history of discrimination against blacks has marginalized the community and "stifled political participation" (2005, 536). When asked about the current disengagement of African-American mosques, one leader answered: "Politics has won little for poor people and has not changed the basic plight of African-Americans. We believe that political involvement entails compromise and corruption of one's principles and dignity" (quoted in Strum 2005, 32). Another study by Karen Isaksen Leonard confirms that African-American Muslims have often remained skeptical of the political process: "[African-Americans] often hold ambivalent or antagonistic views toward the US government. Because Islam is seen as a defense against racism many African-American Muslims argue that asabiyya (group solidarity and experience) must be given priority" over the universal ummah $(2003,8)$. However, while investigating political involvement within the black community, Ihsan Bagby noticed a significant difference between the followers of Imam W. Deen Mohammed and those who seek to follow the Sunnah more closely: $93 \%$ of the former strongly agree that Muslims should be involved in politics, whereas only $49 \%$ of the latter do (Bagby 2004, 14).

The decision to withdraw from the political arena is further made manifest by answers given to a question on the nation's moral values. In 2001 and 2011, respondents were asked whether they felt that American society was immoral. The answers show that black mosque leaders are much more likely than other leaders to agree with that statement. In fact, during this past decade, the percentage of African-American mosque leaders who believe that America is immoral increased from $39 \%$ to $48 \%$ while the number of immigrant leaders decreased from $20 \%$ to $12 \%$. Meanwhile, on this question also, the contrast between the two largest African-American subgroups is similarly observable: $60 \%$ of Imam W. Deen Mohammed's followers agree that America is immoral, compared to $83 \%$ of the more conservative branch (Bagby 2004, 8). In substance, the African-American Muslim group appears to be divided over issues of political implication as a result of differing perspectives on doctrinal rules. That being said, black leaders are overall more readily and openly critical of America than other leaders and because they tend to be better off, recent immigrants are more likely to express satisfaction with the state of the nation. 
Providing insights into how American Muslims define their political priorities, Bagby's reports show that there are broader issues that further divide the constituency. When asked about their main political concern, immigrant Muslims report being more sensitive to foreign affairs. Their focus remains on their homelands and US foreign policy issues affecting the Islamic world such as the Palestine-Israel conflict, US sanctions against Iraq or engagement in Syria. In reaction, African-American Muslims have expressed their disapproval and disappointment. Such is Abdin Chande's observation:

African-American Muslims cannot understand why immigrants send donations to all sorts of causes in other countries, forgetting to address the economic plight of their religious compatriots in the US. So, they do not understand why prayers are addressed to God to ease the problems of Muslims [...] in Iraq, whereas no mention is made of the problems of the inner city dwellers in the US to the total disregard of the reality of America. (2008, 77)

In contrast, African-American Muslims generally tend to focus on domestic issues. For example, when asked whether they felt that their mosque "is working for social justice," $87 \%$ of African-American Muslims answered positively compared to $71 \%$ of all mosques (Bagby 2001, 27). Similarly, another study by Ihsan Bagby in 2005 reveals that African-Americans give a higher priority to providing services to the congregants: services to Muslims are ranked fourth among Black participants as opposed to seventh for Arabs (32). In many of the mosques attended by African-American Muslims, particular programs are designed to provide health care services, support for the destitute and other forms of assistance. In fine, structured inequalities and economic hardship appear to be the main focus of AfricanAmerican mosque activism. This divergence in concerns has obviously constrained the efforts made by community leaders to close the gap between the immigrant and indigenous communities. But it has also translated into differing voting patterns. Indeed, the analysis of recent voting behavior indicates that when going to the poll, subgroups do not form a consistent voting bloc.

The hypothetical existence of a "Muslim lobby" was first extensively reported in the aftermath of the controversial 2000 presidential election. In seeking to identify those who had cast their ballot in favor of the Republican candidate, the New York Times, for example, indicated that: "A few hundred votes decided the election; an estimated 60,000 Muslims in Florida voted 
for Bush" (Senzai 2004, 2). Once the results were settled and announced, Agha Saeed, the chairman of the American Muslim Political Coordination Council (AMPCC), ${ }^{6}$ further corroborated the theory and declared: "It won't be long before political analysts realize that Muslim voters have played a historic role" (quoted in Unger 2004, 216). Although it is quite obvious that at the time Muslim activists sought to weld the community's constituent parts into a unified voting bloc, more recent research shows that the situation was far more complex. In reality, while it is true that the political action committees of immigrant Muslims had endorsed George W. Bush before the election, a majority of African-American Muslims actually gave their vote to the Democratic candidate Al Gore. The key reason for this disagreement was the fact that, aside from being a devout orthodox Jew, Gore's vice-presidential nominee Joseph Lieberman had expressed pro-Israel sentiments in public debates. So his presence on the Democratic ticket did not make Al Gore an acceptable choice for those American Muslims of Middle-Eastern descent. As a result, in the Detroit Metro Area for example, $74 \%$ of Arab Muslims threw their support behind George W. Bush while the majority of native-born black Muslims voted, as most African-Americans have done for decades, for the Democratic candidate (Jamal 2005, 541).

Thus, the existence of a so-called "Muslim lobby" ought to be reconsidered or used with great care. Indeed, formulating a united political platform between immigrant and indigenous Muslims in general has turned out to be a major bone of contention. Clearly, homeland politics or foreign policy are subjects that affect voting trends, and historical trajectories or inherited loyalties continue to shape attitudes. Although countering the daily stereotyping of Muslims in the media and public discourse has taken center stage in US Muslim activism, the lack of a unified socio-political platform has hampered the community's efforts toward a collective agenda and its effectiveness in defining a more inclusive identity.

\section{Conclusion}

On a television appearance in November 2015, Representative Keith Ellison, one of two Muslims in the US Congress, argued that American Muslims needed to assert their "Muslim Americanness" and thus con-

6 The AMPCC was a short-lived umbrella organization founded during the 2000 presidential election campaign to act as a nationwide and united lobbying force. 
firm their sense of belonging and adherence to national cohesion (Kopan 2015, 1).

However, this study has revealed that when identity options are selected and hierarchized, intra-communal dynamics may lead to separate congregations of racial subgroups. Race relations as they have evolved in the US greatly affect the visibility and political stances of the Muslim population. In times of hostility, community leaders strive to delineate clear boundaries and establish their own overarching constituency in order to counter the increasing influence of Islamophobia. But because the black-white racial binary is so firmly rooted, the coming together of the various socio-economic groups is rendered virtually impossible.

My analysis of Ihsa Bagby's reports further shows that between 2001 and 2011 the gap widened between the Arab and indigenous subgroups. It indicates that the fragmentation which was underway before the 9/11 terrorist attacks has continued despite the leadership's call for unity. In fact, in a curious paradox, some black Muslims are now espousing a new form of nativism to preserve the legacy of the African-American experience in North America and promote their legitimacy as genuine Muslims. At the same time, immigrants, and Middle-Easterners specifically, have made little progress in their move away from parochialism. Hence it appears that, although inequalities are fundamentally socio-economic, the concerted reference to a canonical faith or the adoption of long-established racial prejudices has made social progress and equality more difficult to attain between subgroups.

Ultimately, the very particular histories of African-Americans and Arab immigrants and distinct relations vis-à-vis American whiteness make clear the limits of ummah ideals in a society still struggling with race and class inequalities. When asked about the present state of the American Muslim community, one African-American leader conceded: "We are a family. But a very dysfunctional family" (Saafir 2016).

\section{Bibliography}

Adil, James. 2009. "Mayoral Candidates Speak to Muslims at the Islamic Center of Detroit (ICD)". The Muslim Observer. Accessed November 10, 2017. Muslimobserver.com

Bagby, Ihsan et al. 2001. "The Mosque in America: A National Portrait, 2001." Hartford Institute for Religious Research. Accessed February 16, 2017. http://www.cairnet.org/ mosquereport/Masjid_Study_Project_2000_Report.pdf.

. 2004. A Portrait of Detroit Mosques: Muslim Views on Policy, Politics and Religion. 
Clinton Township, MI: Institute for Social Policy and Understanding.

2006. "Isolate, Insulate, Assimilate: Attitudes of Mosque Leaders toward America."

In The Politics of Pluralism in Multireligious America, edited by Stephen Prothero, 23-

42. Chapel Hill: University of North Carolina Press.

2004. "The mosque and the American Public Square." In Muslims' Place in the

American Public Square: Hope, Fears, and Aspirations, edited by Zahid H. Bukhari et al, 323-346. Walnut Creek, CA: AltaMira Press.

2011. "The American Mosque 2011: Basic Characteristics of the American Mosque, Attitudes of Mosque Leaders." CAIR. Accessed January 21, 2017. https://www.cair. $\mathrm{com} / . . . /$ The-American-Mosque-2011-part-1.pdf.

Chande, Abdin. 2008. "Islam in the African American Community: Negotiating between Black Nationalism and Historical Islam." Islamic Studies 47: 2, 221-241. Accessed January 21, 2017.

http://www.jstor.org.lama.univ-amu.fr.

Council on America-Islamic Relations. 2015. "Interview: CAIR Seeks to Boost Muslim Political Involvement.” Washington DC: Council on American-Islamic Relations, March 11. Accessed January 25, 2017.

http://www.cair.com/press-center/cair-in-the-news/6150-interview-cair-seeks-to-boostmuslim-political-involvement.html.

Curtis IV, Edward E. 2002. Islam in Black America: Identity, Liberation and Difference in African American Islamic Thought. Albany, NY: State University of New York Press.

Elass, Rasha. 2015. "Turkey to open major Islamic centre near Washington." The Arab Weekly, September 18. Accessed March 5, 2017.

http://www.thearabweekly.com/Opinion/2048/Turkey-to-open-major-Islamic-centre-nearWashington.

Haddad, Yvonne Y. and John Esposito. 2001. Muslims on the Americanization path? New York: Oxford University Press.

Hall, Timothy L. 2003. American Religious Leaders. New York: Facts on File.

Ileri, Kasim. 2016. "Islam rejects terrorism, Gormez tells American Muslims." Andolu Agency, February 4. Accessed January 21, 2017.

http://aa.com.tr/en/world/islam-rejects-terrorism-gormez-tells-american-muslims/547935.

Jackson, Sherman A. 2009. Islam and the Problem of Black Suffering. New York: Oxford University Press.

Jamal, Amaney. 2005. "The Political Participation and Engagement of Muslim Americans: Mosque Involvement and Group Consciousness." American Politics Research, 33/4: 521-544. Accessed February 27, 2017.

http://citeseerx.ist.psu.edu/viewdoc/download?doi=10.1.1.527.8834\&rep=rep1\&type=pdf.

Karim, Jamillah. 2009. American Muslim Women: Negotiating Race, Class, and Gender with the Ummah. New York: New York University Press.

Kopan, Tal. 2015. "Keith Ellison: Community to Assert Muslim-Americanness." CNN Politics, Nov. 19. Accessed March 12, 2017. http://edition.cnn.com/2015/11/18/politics/ keith-ellison-muslim-american-congress-paris-isis/.

Leonard, Karen Isaksen. 2003. Muslims in the United States: The State of Research. New York: Russell Sage Foundation.

Lipka, Michael. 2017. "Muslims and Islam: Key findings in the U.S. and around the world." Pew Research Center. Accessed January 7, 2017.

http://www.pewresearch.org/fact-tank/2017/02/27/muslims-and-islam-key-findings-in-theu-s-and-around-the-world/.

Loue, Sana. 2006. Assessing Race, Ethnicity and Gender in Health. New York: Springer. 
McCloud, Aminah Beverly. 1994. "Racism in the Ummah." In Islam: A contemporary Perspective edited by Mohammed Ahmadullah Siddiqi, 73-80. Chicago: NAAMPS Publications.

1995. African American Islam. New York: Routledge.

. 2004. "A Challenging Intellectual Heritage: A Look at the Social and Political space of African American Muslims." In Islam in America, edited by P. Strum and D. Tarantolo. Washington D.C.: Woodrow Wilson Foundation Press.

Mohamed, Besheer. 2016. "A New Estimate of the U.S. Muslim Population.” Pew Research Center. Accessed January 7, 2017.

http://www.pewresearch.org/fact-tank/2016/01/06/a-new-estimate-of-the-u-s-muslim-population/.

MuslimARC. 2016. “Our Mission and Three Purposes.” Accessed April 5, 2017.

http://www.muslimarc.org/about/.

Muslim Communities Association of South Florida (MAC). 2002. "About Islam”. Accessed April 12, 2017.

http://miamimuslim.org/about-islam/.

Naber, Nadine. 2012. Arab America: Gender, Cultural Politics, and Activism. New York: New York University Press.

Neuhaus, Richard John. October 2001. "One Nation Under Many Gods.” First Things. Accessed May 2, 2017.

www.firstthings.com/article/2001/one-nation-under-many-gods.

Nimer, Mohammed. 2002. "Muslims in American Public Life." In Muslims in the West: from Sojourners to Citizens, edited by Yvonne Yazbeck Haddad, 169-186. New York: Oxford University Press.

Pew Research Center. 2011. "Muslim Americans: No Sign of Growth in Alienation or Support for Extremism." Accessed April 1, 2017.

http://www.people-press.org/2011/08/30/muslim-americans-no-signs-of-growth-in-alienation-or-support-for-extremism/.

. 2007. "Muslim Americans: Middle Class and Mostly Mainstream." Accessed April 6, 2017.

http://www.pewresearch.org/2007/05/22/muslim-americans-middle-class-and-mostlymainstream/.

Reich, Simon and Ariane Chebel d'Appollonia. 2010. "Quandaries of Integration in America and Europe: An Introduction.” In Managing Ethnic Diversity after 9/11: Integration, Security, and Civil Liberties in Transatlantic perspective, edited by Chebel d'Appollonia and Simon Reich, 1-19. New Brunswick: Rugters University Press.

Ruiter, S. and De Graaf, N. D. 2006. "National Context, Religiosity, and Volunteering: Results from 53 Countries.” American Sociological Review 71: 191-210.

Saafir, Jihad. 2016. "The African-American Political Experience". Filmed December 30. Youtube video, 16:30. Posted December 2016.

https://www.youtube.com/watch?v=vJQ3gprxmH8.

Senzai, Farid. 2012. "The Muslim Swing Vote." The New York Times, April 2. Accessed April 10, 2017.

https://campaignstops.blogs.nytimes.com.

Sharp, Gregory, and John Iceland. 2013. "The Residential Segregation Patterns of Whites by Socioeconomic Status, 2000-2011.” Social Science Research 42 (4): 1046-1060.

Sirin, Selcuk R., and Michelle Fine. 2008. Muslim American Youth: Understanding Hyphenated Identities through Multiple methods. New York and London: New York University Press. 
Strum, Philippa (ed.). 2005. Muslims in the United States: Identity, Influence, Innovation. Washington DC: Woodrow Wilson International Center for Scholars. Accessed February 11,2017 .

https://www.wilsoncenter.org/site/default/files/Muslim_Thought_final.pdf.

Unger, Craig. 2004. House of Bush, House of Saud: The Secret Relationship between the World's Two Most Powerful Dynasties. New York: Scribner.

Unmosqued. 2013. Directed by Ahmed Eid. Mountain View, CA: Eid films. 